\title{
Kebijakan Kriminal Di Bidang Konservasi Keanekaragaman Hayati
}

Saifullah

Dosen Fakultas Syariah UIIS Malang

\begin{abstract}
The study is aimed at analyzing the implementation and the perspectives of criminal policies in the field of biodiversity conservation. Reevaluation on penal policies is focused on five concepts. Therefore, it is necesarry to recheck the terminology of flora and fauna using a method of categorizing for all flora and fauna becoming the results of the real development in the field in relation to the category standard of IUCN using the final version of 1994 or CITES Appendix,. Non penal policies which have been applied by the program organizers are adapted to the data field through PRA (Participatory Rural Appraisal) studies. Reevaluation on non penal policies have been elaborated in details in both two programs

Reevaluation mentioned above is useful for constructing perspective by considering the recommendation on criminal policies in the United Nations Congress: CITES, KTT Land Document in Rio de Janeiro 1992, and Global Biodiversity Strategies of 1992, national conferences for experts of criminal laws of natural environment and comparative study in criminal policies an natural environment in other countries.

The theoretical and practical contributions of criminal policies in biodiversity conservation are valued as a paradigm in the contexts of: (1) the effects of internal and external affairs based on democracy principles on the existence of criminal policy, (2) the position of criminal policy in the paradigm of law reformation in Indonesia.
\end{abstract}

Ulul Albab, Vol. 4 No. 1, 2002 


\section{A. Latar Belakang Masalah}

Potensi sumber daya alam dan energi, baik itu renewable resources, unrenewable resources maupun continuous resources sangat penting artinya bagi kelangsungan regenerasi kehidupan manusia. Sumber daya alam hayati atau keanekaragaman hayati merupakan sumber daya alam yang dapat diperbaharui (renewable resources) dan dimanfaatkan bagi berbagai aspek kebutuhan kehidupan manusia seperti pangan, sandang, papan, obat-obatan, nilainilai ritual, pendidikan, penelitian ilmu pengetahuan, menunjang budidaya, budaya dan pariwisata, rekreasi sampai pada nilai estetika. Pemanfaatan keanekaragaman hayati tersebut dapat terkendali jika dikelola sebagai mana mestinya sesuai dengan kaidah konservasi.

Potensi keanekaragaman hayati yang ada di Indonesia diakui sebagai salah satu negara mega biodiversity di dunia dan hanya dapat diungguli Brazil (Amerika Selatan) dan Zaire (Afrika). Akan tetapi keberadaan keaneka-ragaman hayati ini telah mengalami degradasi kualitas maupun kuantitas yang disebabkan oleh berbagai tindakan manusia diantaranya eksplorasi, eksploitasi, perusakan dan pencemaran, pencurian dan penjarahan, terjadinya kebakaran hutan, erosi dan bencana lainnya sehingga mengakibatkan musnahnya berbagai flora dan fauna yang pada gilirannya mengakibatkan flora dan fauna menjadi punah.

Kecerobohan manusia tersebut telah menghilangkan lebih dari 400 jenis makhluk dalam waktu 40 tahun terakhir ini. Merosotnya kualitas dan kuantitas keanekaragaman hayati tersebut merupakan salah satu isu global dunia yang menjadi beban negara tropika yang kaya akan keanekaragaman hayati termasuk Indonesia.

Pada masa mendatang, keanekaragaman hayati akan memegang peranan lebih penting lagi dalam pembangunan nasional karena kebutuhan dunia terhadap bahan-bahan hayati baru untuk obat, varietas baru tanaman pertanian dan ternak, proses industri, dan pengolahan bahan limbah. Prospek ini tidak akan dapat diraih Indonesia jika erosi keanekaragaman hayati di Indonesia, baik dari segi ekosistem, spesies maupun genetik, masih cukup mengkhawatirkan seperti sekarang ini. Berbagai faktor, diantaranya eksploitasi sumber daya alam yang berlebihan, kerusakan habitat alami akibat tekanan terhadap lahan dari pembangunan dan pertanian, pencemaran sungai, lahan basah serta lautan, dan introduksi spesies eksotik telah menyebabkan degradasi keanekaragaman hayati. Faktor ini terkait 
pula dengan kebijakan dan peraturan yang memungkinkan terjadinya erosi keanekaragaman hayati.(BAPPENAS, $1993: 3-4)$.

Kekayaan keanekaragaman hayati, saat ini dirasakan oleh berbagai negara di dunia pada umumnya dan Indonesia pada khususnya berada dalam kondisi menurun. Dalam "Twelve Critical Issues Environment" seperti yang diutarakan Lynton Keith Cadwell degradasi keanekaragaman hayati menempati posisi pertama dan kedua yaitu : (1) kehilangan unsur-unsur genetik (2) gangguan dan kehancuran ekosistem. ${ }^{2}$ Peringkat pertama dan kedua yang diutarakan oleh Lynton Keith Cadwell tersebut menjadikan kondisi keanekaragaman hayati di dunia patut untuk diperhatikan dan dicari jalan keluar secara serius.

Uraian latar belakang masalah di atas juga didasari atas beberapa pertimbangan pemikiran yang bersumber dari data primer maupun data sekunder sebagai berikut :

1. Sejak dilakukannya KTT Bumi 1992 di Rio de Janeiro yang merekomendasikan persoalan lingkungan ke dalam agenda perdagangan internasional. Hal ini menjadi penting bagi keselamatan dan kesinambungan dunia, karena isu lingkungan pun telah dimasukkan menjadi agenda perdagangan regional NAFTA (North America Free Trade Area). Begitu pula halnya dalam Asosiasi Perdagangan Asia Pasifik (APEC), para Menteri Lingkungan Hidup pada pertemuan 1994 telah membentuk Environment Vission Statement and Principles. Menyusul ISO (International Standardization Organization) seri 14000 yang mengatur Environment Management System untuk standar perdagangan internasional dan sangat menentukan bagi keberhasilan hasil-hasil industri suatu negara (yang bersahabat dengan lingkungan atau ecolabelling) untuk bersaing di pasar bebas internasional di tahun 2003. Dengan demikian persoalan lingkungan menjadi semakin kompleks. Tidak hanya bersifat praktis, konseptual, ekonomi saja tetapi juga merupakan masalah etika baik sosial maupun bisnis. Sedangkan yang dilindungi oleh hukum (pidana) tidak hanya alam, flora dan fauna (the ecological approach), tetapi juga masa depan kemanusiaan yang kemungkinan menderita akibat degradasi lingkungan hidup (the anthoropcentric approach). Dengan demikian muncul istilah "the environmental laws carry penal sanctions that protect a multitude of interest". ${ }^{3}$ 
2. Dalam Ninth United Nation Congress on the Prevention of Crime and The Treatment of Offenders (Cairo, Egypt, 29 April - 8 May 1995), aspek kejahatan konservasi hayati (flora dan fauna) merupakan kecenderungan kejahatan internasional dalam "aturan hukum pidana dalam melindungi lingkungan" (The role of criminal law in the protection of the environment) sehingga memerlukan perhatian yang mendesak dengan penggunaan hukum pidana dalam melindungi lingkungan.

3. Laporan tentang kondisi bumi diungkapkan oleh WALHI pada peringatan hari bumi (22 April 1998) bahwa luas hutan Indonesia yang pada dekade 30-an mencapai 143 juta hektar, tahun ini diperkirakan tinggal 53 juta hektar. Angka deforestasi per tahun mencapai 2,4 juta hektar. Angka penciutan lahan tropik ini adalah jauh lebih tinggi dari rata-rata dunia yang setiap tahun mencapai 978 ribu hektar. Di laut menunjukkan $70 \%$ terumbu karang telah nusak dan hutan bakau dengan total luas 3 juta hektar saat ini hanya tersisa 36\%. Akibat adanya pembukaan hutan selama ini, ternyata telah kehilangan 104 jenis burung, 57 jenis mamalia, 21 jenis reptil, 65 jenis ikan air tawar dan 281 jenis tumbuhan. Data dari WALHI telah menjadikan Indonesia sebagai negara yang memiliki daftar spesies terancam punah terpanjang di dunia.

4. Menurut hitungan Kantor Menteri Negara Lingkungan Hidup, kini ada 126 jenis burung, 63 jenis mamalia, dan 21 jenis reptil yang populasinya menurun. Kondisi inilah yang disebut oleh John C. Ryan sebagai "proses pemiskinan hayati"4 yang sedang melanda seluruh muka bumi. Seperti kejadian pada akhirakhir ini berupa kebakaran hutan di beberapa wilayah Indonesia, selain menimbulkan pencemaran udara (seperti asap) ke negara tetangga juga menimbulkan dampak negatif seperti rusak dan punahnya sumber daya alam hayati dan pemulihan kembali memerlukan waktu lama. Sampai saat ini belum terdapat data akurat untuk mendeteksi jumlah serta spesies dari flora dan fauna yang punah akibat kebakaran. Kerugian akibat kebakaran hutan dan lahan menurut taksiran WALHI senilai 6,2 triliun rupiah. Ini didasarkan atas kerusakan hutan, berhentinya penerbangan, kerugian di sektor pariwisata, jumlah korban yang jatuh dan hilangnya berbagai hasil panen masyarakat. Menurut perhitungan WALHI dari jumlah hot spot, kebakaran hutan tahun ini mencapai luas 1,174 juta hektar. Kebakaran tersebut mengakibatkan kerugian warga masyarakat yang berjumlah sekitar 20 juta orang. Menurut Asisten II Menteri Negara 
Lingkungan Hidup, Hadi.S.Alikodra dibutuhkan waktu sekitar 50 tahun untuk memulihkan hutan dan lahan di Kalimantan Timur yang kini terbakar, mengingat kebakaran telah memusnahkan sistem biologis yang menjadi urat nadi hutan. Sedangkan sebanyak 154 pengusaha HPH/ HTI dan perkebunan dicabut izinnya karena terbukti membakar hutan untuk membuka lahan usaha mereka. Sebanyak 26 perusahaan diantaranya diajukan ke polisi untuk di proses lebih lanjut karena dicurigai tindakan mereka dilakukan dengan sengaja.

5. Data dari Indonesian Center for Environmental Law (2002) menyebutkan bahwa : (a) deforestasi hutan di Kalimantan, Sumatera, Sulawesi dan Papua) antara tahun 1985-1997 sebesar 1,7 juta hektar/tahun (estimasi Dephut 0,6 1,3 juta hektar/tahun) sedangkan illegal logging mulai tahun 1994-1997 sebesar 20 juta $\mathrm{m} 3 /$ tahun dengan modus : menebang kayu di kawasan lindung, melanggar ketentuan-ketentuan HPH, dll. (b) kebakaran hutan yang terjadi sepanjang tahun 1997-1998, areal yang terbakar 9,7 juta hektar (4,8 juta hektar areal hutan). Kenugian ekonomi sebesar 9,3 milyar dolar US dan 7,9 juta dolar US merupakan beban masyarakat dan dunia usaha. 1,4 juta dolar US merupakan beban global yang diakibatkan oleh perubahan iklim global. Penyebabnya adalah $34 \%$ diakibatkan oleh konversi lahan dalam skala besar ; $25 \%$ peladang berpindah ; $17 \%$ pertanian, $14 \%$ kelalaian manusia dan konflik masyarakat dengan pemegang konsesi ; $8 \%$ proyek transmigrasi, dan $1 \%$ diakibatkan oleh alam. (c) perusakan terumbu karang pada sumber daya perikanan dan kelautan, $7 \%$ dalam keadaan baik, $70 \%$ dalam keadaan yang sangat rusak (OJL-LIPI). (d) Kondisi penegakan hukum (adminsitrasi ) di bidang lingkungan hidup di provinsi Jawa Barat dari 237.232 industri, monitoring yang mampu dilakukan : tahun 1996-1997 : hanya 130 fasilitas (80\% tidak memenuhi kriteria standard lingkungan ) ; tahun 1998-1999 : hanya 80 fasilitas ; tahun 1999-2000 : pemantauan dihentikan karena tidak ada dana. Untuk Jawa Tengah dari 2383 industri yang berpotensi mecemarkan, 219 yang diteliti, kurang dari $10 \%$ punya IPAL. Pemantauan 1 bulan $1 \mathrm{kali}$ oleh satgas bersama dan staff hanya 5 orang yang melakukan inspeksi. Khusus di Semarang dari hasil laporan World Bank tahun 1998 dari 121 fasilitas yang diteliti, 60 \% dikategorikan "do nothing" dan sisanya dari kelompok "do something" sebesar $39 \%$, hanya $27 \%$ dari industri punya IPAL. Kurang dari $1 \%$ dari total investasi. 
6. Kajian yang dilakukan oleh Dirk Bryant, Daniel Nielsen and Laura Tangley $^{6}$ yang memperkenalkan Index Frontier Forest. Indeks ini didapat dari hasil studi di sektor kehutanan di hampir seluruh belahan dunia dengan mematok skor 99 sebagai skor terjelek. Index World Resources Institute tentang Frontier Forest (FF) membagi empat kategori besar. Kategori pertama ditujukan bagi negara-negara yang telah kehilangan semua FF-nya. Sebanyak 76 negara masuk dalam kategori pertama, ini termasuk hampir semua negara di benua Eropa, Afrika Timur, Afrika Utara dan Timur Tengah. Bagi mereka perbaikan hutan haruslah menjadi prioritas utama. Kategori kedua bagi negara dalam batas kondisi kritis. Sebelas negara lainnya termasuk Nigeria, Thailand, Swedia, Finlandia dan Guatemala diklasifikasikan dalam kategori kedua. Hanya 5\% hutan asli mereka masih tersisa, ini pun dalam kondisi kritis. Kategori ketiga bagi mereka yang masih mempunyai FF tetapi sangat berpacu dengan waktu untuk mempertahankannya. 28 negara termasuk Malaysia, Papua Nugini, Indonesia, Argentina dan India terhitung dalam kategori ketiga ini. Negara ini banyak kehilangan FF-nya, sedang yang tersisa sangat terancam keberadaannya. Kategori keempat adalah negara-negara yang masih mempunyai kesempatan besar untuk mempertahankan FF-nya yaitu Brasil, Suriname, Guyana, Kanada, Kolombia, Venezuela dan Rusia. Negara ini masih mempunyai kesempatan luas untuk menjaga sisa hutan alaminya jika mereka mulai untuk menerapkan prinsip perlindungan hutan sejak sekarang. Dengan skor 39, Indonesia diperkirakan masih mempunyai 530 ribu $\mathrm{km}^{2} \mathrm{FF}$, $4 \%$ dari FF dunia, jauh lebih rendah ketimbang Rusia (26\% dengan skor 13 ) atau Kanada (25\% dengan skor 8). Temuan mutakhir ini mendorong kita untuk melakukan aksi konkrit untuk menyelamatkan fungsi hutan dan utamanya menjaga keanekaragaman hayati.

7. Di Indonesia, kerusakan maupun kepunahan keanekaragaman hayati dan nonhayati disebabkan pula oleh aktifitas perusahaan-perusahaan tambang, pengusaha perkebunan maupun pengusaha HPH yang menerobos kawasan konservasi yang diduga meniliki sumber daya alam hutan yang menguntungkan.

Di samping itu, penyerobotan atau perambahan kawasan konservasi juga dilakukan oleh pengusaha yang wilayah konsesinya berdekatan dengan kawasan konservasi. Demikian pula pembukaan lahan atau pembersihan lahan dengan membakar yang dilakukan secara tidak hati-hati telah menyebabkan sejumlah 
kawasan lindung turut terbakar dan musnah dimakan api. Kerugian yang diderita diantaranya adalah eksistensi masyarakat adat untuk melakukan aktifitasnya mengalami gangguan utamanya pelestarian nilai-nilai kearifan ekologis.

Pemaparan fakta-fakta di atas memberikan gambaran bahwa kondisi keanekaragaman hayati sudah sedemikian parah sebagai akibat dari perilaku manusia terhadap alam. Secara sunatullah, proses suksesi dalam mata rantai kehidupan keanekaragaman hayati akan berjalan dengan sendirinya. Kondisi suksesi alamiah ini mengalami gangguan bilamana terjadi intervensi perilaku manusia. Dalam pandangan inilah, maka perilaku manusia yang merugikan tidak saja pada keutuhan keanekaragaman hayati tetapi juga bagi kesinambungan kehidupan manusia. Perilaku manusia yang terkategorikan sebagai kejahatan tersebut, merupakan kejahatan terhadap kualitas lingkungan hidup (crime againts the quality of life) yang secara langsung berkaitan dengan masalah kejahatan terhadap pembangunan (crime againts development) dan kejahatan terhadap kesejahteraan sosial (crime againts social welfare). Kejahatan yang dilakukan manusia terhadap keutuhan keanekaragaman hayati secara ex-situ maupun in-situ di kawasan konservasi merupakan kejahatan di bidang lingkungan hidup yang spesifik, oleh karena korban kejahatan yang terjadi adalah punahnya flora dan fauna, sedangkan kawasan konservasi merupakan satu-satunya wadah pelestarian secara alamiah bagi kekayaan plasma nutfah. Ciri-ciri ini sangat berbeda dengan jenis-jenis perbuatan pidana di bidang lingkungan hidup yang biasa dikenal masyarakat selama ini, seperti kasus-kasus pencemaran maupun perusakan lingkungan. Dalam wacana keilmiahan (scientific discourse), kajian terhadap perbuatan pidana di bidang konservasi keanekaragaman hayati dari berbagai aspek yang penulis ketahui untuk saat ini relatif belum mendalam. Untuk itu, perlindungan hukum terhadap kekayaan flora dan fauna secara ex-situ maupun in-situ di kawasan konservasi menjadi urgen untuk diteliti.

\section{B. Rumusan Masalah}

Pengkajian dimulai dengan meneliti tingkat kerusakan atau kepunahan flora dan fauna, jumlah flora dan fauna yang telah punah, spesies baru yang telah ditemukan serta faktor penyebab dari punahnya flora dan fauna di kawasan 
konservasi. Kajian implementasi kebijakan kriminal melalui kebijakan penal akan diteliti tentang kebijakan legislatif dalam memformulasikan perbuatan pidana, pertanggungjawaban pidana dan sanksi pidana dalam peraturan perundang-undangan di bidang konservasi keanekaragaman hayati, sedangkan dari aspek kebijakan nonpenal akan dikaji tentang operasionalisasi program konservasi keanekaragaman hayati yang telah dirumuskan oleh Balai Konservasi Sumber Daya Alam (Balai KSDA) dan Balai Taman Nasional (BTN). Selain hal itu, diteliti pula kendala yang ditemui dalam implementasi program konservasi keanekaragaman hayati melalui kebijakan penal dan kebijakan nonpenal.

Masalah kedua yang penulis teliti mengenai perspektif kebijakan kriminal di bidang konservasi keanekaragaman hayati dalam rangka menunjang pembangunan berkelanjutan yang berwawasan lingkungan. Penelitian diawali dengan re-evaluasi terhadap paradigma kebijakan kriminal di bidang konservasi keanekaragaman hayati. Mengacu pada konsepsi pemikiran G. Peter Hoefnagels dan perkembangan wacana kebijakan kriminal selanjutnya dianalisis berdasarkan hasil temuan penelitian pada masalah yang pertama. Analisis tersebut selanjutnya memaparkan hal-hal yang ditemui dalam kajian kebijakan kriminal di bidang konservasi keanekaragaman hayati serta memberikan alternatif perspektif kebijakan kriminal di bidang konservasi keanekaragaman hayati. Kajian tentang perspektif ini dilengkapi pula dengan rekomendasi kebijakan kriminal yang dibicarakan dalam Kongres PBB tentang The Prevention of Crime and The Treatment of Offenders, pertemuan internasional lainnya mengenai hukum perlindungan flora dan fauna serta kebijakan kriminal di bidang lingkungan hidup di berbagai negara.

\section{Kerangka Pemikiran Konsepsional}

Titik tolak kajian implementasi kebijakan kriminal di bidang konservasi keanekaragaman hayati dimulai dari kebijakan penal yang memformulasikan perilaku manusia yang mengakibatkan kerusakan dan kepunahan keanekaragaman hayati baik disengaja maupun tidak disengaja. Aspek kriminalisasi perilaku tersebut mempunyai dimensi penting untuk ditanggulangi. Sebagai usaha untuk menanggulangi kejahatan di bidang konservasi keanekaragaman hayati, kebijakan kriminal yang dikembangkan oleh G. Peter Hoefnagels ${ }^{7}$ merupakan titik tolak kajian kebijakan kriminal dalam penelitian ini. 
Dalam diagram kebijakan kriminal yang diajukan oleh G. Peter Hoefnagels terlihat jelas pembagian dari kebijakan kriminal yaitu influencing view of society on crime and punishment (mass media) dan prevention without punishment yang tergolong sebagai nonpenal policy serta criminal low application (practical criminology) sebagai penal policy. Muladi dalam wacana lain menyebutkan bahwa kebijakan penal bersifat refresif karena menggunakan sarana penal, yang sering disebut dengan sistem peradilan pidana. Dalam hal ini secara luas sebenarnya juga mencakup pula proses kriminalisasi. Kebijakan nonpenal berupa usaha-usaha tanpa menggunakan sarana pidana dan mendayagunakan usaha-usaha pembentukan opini masyarakat tentang kejahatan dan sosialisasi hukum melalui mass media secara luas. Kebijakan penal atau kebijakan hukum pidana yang terejawantah dalam criminal justice system dapat berwujud memfungsikan hukum pidana dalam menanggulangi kejahatan yang terdiri atas tiga tahap yaitu tahap kebijakan formulatif, tahap kebijakan aplikatif dan tahap kebijakan eksekutif. Dalam telaah substansi hukum pidana, maka tahap kebijakan formulatif dapat dilihat sebagai dasar atau landasan bagi tahap-tahap fungsionalisasi/ penegakan hukum pidana berikutnya. Oleh karena itu tahap kebijakan formulatif merupakan tahap yang paling strategis.

Kebijakan hukum pidana di bidang konservasi keanekaragaman hayati di sini mengkaji kebijakan formulasi perbuatan pidana, pertanggungjawaban pidana dan sanksi pidana yang dirumuskan oleh pembentuk undang-undang dan selanjutnya aspek pengimplementasian kebijakan formulatif oleh aparat penegak hukum. Kebijakan memformulasikan perbuatan pidana dan sanksi pidana dalam peraturan perundang-undangan bukanlah pekerjaan yang mudah. Proses memfungsionalisasikan hukum pidana dalam kebijakan formulatif ini, tujuannya tidak sekedar dibuat untuk jangka waktu tertentu melainkan digunakan untuk menanggukangi kejahatan dalam waktu yang relatiflama. Dengan demikian proses penetapan kebijakan formulatif ini harus mampu menghasilkan rumusan yang bersifat prediktif dan antisipatif guna mengikuti perkembangan zaman.

Bertitik tolak dari pemikiran di atas maka pengkajian kebijakan kriminal di bidang konservasi keanekaragaman hayati seyogyanya ditempuh dengan pendekatan integral, baik dengan menggunakan kebijakan penal maupun kebijakan nonpenal. Pendekatan integral merupakan pendekatan saling keterpaduan antara kebiajakan penal maupun kebijakan nonpenal dalam menanggulangi kejahatan yang terjadi dalam masyarakat. 
Mengingat upaya penanggulangan kejahatan lewat jalur "nonpenal" lebih bersifat tindakan pencegahan untuk terjadinya kejahatan, maka sasaran utamanya adalah menangani faktor-faktor kondusif penyebab terjadinya kejahatan. Faktorfaktor kondusif itu antara lain berpusat pada masalah-masalah atau kondisi-kondisi sosial yang secara langsung atau tidak langsung dapat menimbulkan atau menumbuh suburkan kejahatan. Dengan demikian dilihat dari sudut kebijakan kriminal secara makro dan global, maka upaya-upaya nonpenal menduduki posisi kunci dan strategis dari keseluruhan upaya kebijakan kriminal. ${ }^{9}$

Menganalisis wacana kebijakan kriminal di atas, serta didasari oleh pertimbangan dalam latar belakang studi menunjukkan bahwa : degradasi keanekaragaman hayati terjadi karena prilaku manusia terhadap lingkungan hidup. Oleh sebab itu pengendalian perilaku manusia menjadi penting untuk diperbaiki melalui pendekatan kebijakan kriminal dalam upaya menanggulangi kejahatan di bidang konservasi keanekaragaman hayati.

Untuk mewujudkan upaya kebijakan kriminal di bidang konservasi keanekaragaman hayati dibutuhkan birokrasi yang keberadaannya berfungsi sebagai melaksanakan program-program pemerintah sampai di tingkat yang paling bawah. Kehidupan masyarakat dalam era global ini tidak dapat dipisahkan akan keberadaan birokrasi yang tidak hanya berkaitan dengan persoalan tata atur dan tata awasi dari lembaga pemerintahan secara internal tetapi juga sudah melibatkan kinerja atau partisipasi publik yang sedemikian luas secara eksternal seperti bidang-bidang organisasi sosial keagamaan, perusahaan atau korporasi, perbankan dan lain-lain.

Setelah menelusuri aspek implementasi kebijakan penal dan kebijakan nonpenal di bidang konservasi keanekaragaman hayati maka hasil implementasi tersebut selanjutnya dikaji dalam wacana perspektif kebijakan kriminal dengan sudut pandang pembangunan berkelanjutan yang berwawasan lingkungan (ecologically sustainable development).

Perspektif kebijakan kriminal di bidang konservasi keanekaragaman hayati dimunculkan sebagai sumbangsih pemikiran penulis untuk memprediksi dan mengantisipasi berdasarkan temuan-temuan awal dari implementasi kebijakan kriminal tersebut yang diawali dengan mengevaluasi kembali (re-evaluasi) paradigma kebijakan kriminal konservasi keanekaragaman hayati. 
Upaya kebijakan kriminal sebagai bentuk penanggulangan kejahatan sesungguhnya merupakan bentuk rekayasa sosial yang berwujud pola kebijakan yang menggunakan hukum sebagai alat pembaharuan sesuai dengan perkembangan yang terjadi dalam masyarakat. Sebagai bentuk usaha rasional dari masyarakat untuk menanggulangi kejahatan maka kebijakan kriminal tidak bisa lepas pengaruhnya dari aspek personal maupun sosial baik itu secara internal maupun eksternal. Pengaruh tersebut pada akhirnya memberikan corak bagi keluaran (out $p u t$ ) dari setiap produk kebijakan kriminal. Produk hukum dari kebijakan kriminal yang mampu menyesuaikan dengan perkembangan dalam masyarakat akan menjadikan hukum bersifat responsif terhadap tuntutan perubahan.

\section{Tujuan dan Kontribusi Penelitian}

Asumsi dasar yang dikembangkan dalam kerangka pemikiran kosepsional tentang kebijakan kriminal di bidang konservasi keanekaragaman hayati adalah suatu metode dalam penanggulangan kejahatan yang diupayakan dengan pendekatan secara komprehensif integral. Upaya maksimal kebijakan kriminal tersebut dengan memadukan kebijakan penal dan kebijakan nonpenal nampaknya menjadi pilihan kebijakan dalam upaya menanggulangi kejahatan di bidang lingkungan hidup. Sisi lain yang dikembangkan dalam khazanah ini adalah aspek perspektif kebijakan kriminal dengan mengkaji alternatif-alternatif baru bagi upaya-upaya penanggulangan kejahatan yang lebih maksimal dengan dilandasi prinsip-prinsip konservasi lingkungan hidup.

Searah dengan asumsi di atas maka tujuan dilakukannya penelitian ini adalah : Pertama, mengkaji implementasi kebijakan kriminal di bidang konservasi keanekaragaman hayati dengan dianalisis dari sudut perkembangan wacana pemikiran kebijakan kriminal. Kedua, mengkaji perspektif kebijakan kriminal di bidang konservasi keanekaragaman hayati dalam rangka menunjang pembangunan berkelanjutan yang berwawasan lingkungan (ecologically sustainable development).

Hasil dari penelitian ini diharapkan dapat bermanfaat untuk : Pertama, memberikan masukan atau rekomendasi pada instansi yang terkait serta aparat penegak hukum, utamanya hasil kajian kebijakan kriminal (kebijakan penal dan 
kebijakan nonpenal) di bidang konservasi keanekaragaman hayati yang telah dilakukan selama ini sebagai upaya pembaharuan kebijakan kriminal di masa mendatang. Kedua, melengkapi bahan-bahan studi penelitian serta mengembangkan wacana ilmiah (scientific discourse) sebagai wawasan baru pada khazanah hukum perlindungan lingkungan hidup khususnya kebijakan kriminal di bidang konservasi keanekaragaman hayati.

\section{E. Metode Penelitian}

\section{Paradigma Penelitian dan Pendekatannya}

Paradigma penelitian yang dipergunakan dalam alur kerja penelitian ini menganut paradigma konstruktivisme. Adapun bentuk metodologis dari paradigma ini, dalam hal pengumpulan data dilakukan melalui proses hermeneutics dan dialectics yang difokuskan pada konstruksi, rekonstruksi dan elaborasi suatu proses sosial. Dengan kata lain, teknik penelitian dilakukan dengan observasi, participant observation dan dilakukan dengan wawancara terbuka. Sedangkan bentuk sampel penelitian secara purposive sampling. Kriteria penilaian kualitas penelitian dilakukan dengan standar kredibilitas, transferabilitas, dependabilitas dan konfirmabilitas. Narasi dilakukan dengan interpretasi pada studi kasus berupa deskriptif kualitatif yang berupaya menceritakan (storying) objek penelitian untuk mendekati realitas sosial yang sebenarnya dalam upaya mencari pola, model atau tema. Dari sisi aksiologis, kelompok konstruktivisme melihat nilai, etika dan pilihan moral merupakan bagian yang tidak dapat terpisahkan dalam suatu penelitian. Posisi peneliti ditempatkan sebagai : "transformative intellectual". Tujuan penelitian adalah rekonstruksi realitas sosial secara dialektik antara peneliti dengan aktor sosial yang diteliti sehingga diperoleh pemahaman makna (verstehen) dalam upaya mengembangkan teori dan menggambarkan realitas yang kompleks.

\section{Metode Pendekatan Masalah}

Mengkaji perumusan dan ruang lingkup masalah yang telah peneliti paparkan terdahulu maka metode penelitian ini dilakukan dengan pendekatan secara nondoktrinal yang dilengkapi pula dengan pendekatan doktrinal. Dengan 
mempertimbangkan kajian kebijakan kriminal melalui kebijakan penal dan kebijakan nonpenal dalam upaya penanggulangan kejahatan di bidang konservasi keanekaragaman hayati seperti terurai dalam latar belakang studi maupun anatomi berfikir secara teoritis, maka penggunaan pendekatan tersebut diharapkan mampu menjelaskan secara objektif atas segala permasalahan yang penulis angkat dalam studi ini.

\section{Metode Pengumpulan Data}

\section{a. Studi Lapangan}

Studi lapangan dilakukan dengan mengadakan peninjauan pada kawasan konservasi sebagai sampel dari lokasi penelitian. Peninjauan pada lokasi penelitian tersebut dimaksudkan untuk mendapatkan data primer yang dilakukan dengan metode wawancara bebas terpimpin berpedoman pada kuesioner terbuka.

b. Studi Kepustakan

Bertujuan untuk mendapatkan data sekunder yang berwujud menelaah bahan yang berkaitan dengan hukum perlindungan lingkungan baik itu hasil laporan penelitian, laporan LSM, pendapat para ahli, putusan pengadilan, dokumen-dokumen Kongres PBB serta kajian lintas disiplin seperti : filsafat lingkungan hidup, biologi konservasi, kebijakan publik, sosiologi kriminalitas dan sebagainya yang berkaitan dengan paradigma kebijakan kriminal di bidang konservasi keanekaragaman hayati.

c. Sampel dan Teknik Sampling

Populasi penelitian ini adalah keseluruhan kawasan konservasi yang terdapat dalam Wilayah Balai KSDA se Jawa Timur sedangkan kawasan konservasi yang dijadikan sampel penelitian : 1 lokasi Taman Hutan Rakyat, 3 lokasi Taman Nasional, 2 lokasi Taman Wisata, 1 lokasi kawasan Suaka Margasatwa dan 10 lokasi kawasan Cagar Alam. Dengan demikian teknik penentuan sampel dalam penelitian ini dilakukan secara purposive sampling.

d.Teknik Keabsahan Data

Selama proses pengumpulan data primer dan data sekunder tersebut diupayakan pula penjagaan serta pemeriksaan keabsahan data. Terdapat empat tipe standar yang dapat dilakukan untuk menjamin kesahihan (validitas) dan keandalan (reliabilitas) hasil penelitian seperti yang dikemukakan oleh Yvonna S. 
Lincoln dan Egon G. Guba yaitu kredibilitas, transferabilitas, dependabilitas konfirmabilitas

4. Metode Pengolahan Data

Data primer maupun data sekunder yang dikumpulkan di lapangan dengan lengkap selanjutnya diolah dan dianalisis dengan langkah-langkah : editing, coding, prakoding, membuat kategori untuk mengklasifikasi jawaban, menghitung frekuensi, tabulasi, tabel sebagai kerangka analisa data. ${ }^{10}$ Pengolahan data secara kuantitatif tersebut berfungsi sebagai pendukung data kualitatif. Selain itu dilakukan pula pengolahan data secara kualitatif dengan mendeskripsikannya seutuh mungkin dengan mengupayakan storying mendekati realitas sosial yang terjadi.

5. Metode Analisis dan Penyajian Data

Dengan prosedur penelitian di atas dimaksudkan untuk mendapatkan data primer maupun data sekunder selengkap mungkin sebagai bahan penjelasan terhadap permasalahan yang diajukan. Masalah yang diajukan dianalisis dengan meramunya pada sandaran konseptual atau teori. Analisis data tersebut selanjutnya dilakukan secara kualitatif atau bercerita dengan dukungan dari data kuantitatif di atas. Sedangkan pengkajian rekomendasi dokumen-dokumen Kongres PBB agar mampu untuk diakomodasikan dalam peraturan perundang-undangan di bidang konservasi keanekaragaman hayati dilakukan secara content analysis. ${ }^{11}$.

\section{F. Paparan dan Analisis Data}

Pengkajian tingkat kerusakan, kepunahan maupun spesies baru yang ditemukan dari flora dan fauna di kawasan konservasi dilakukan dengan pemantauan melalui kegiatan perencanaan dan pelaksanaan inventarisasi flora dan fauna sesuai dengan kebutuhan spesifik dari situasi kawasan konservasi yang bersangkutan. Metode inventarisasi flora dan fauna tersebut dapat dibagi dalam 2 (dua) metode : metode secara langsung dan tidak langsung atau "sistem pendugaan". Inventarisasi flora dan fauna yang dilakukan selama ini oleh pengelola konservasi menunjukkan secara umum belum ditemukan adanya metode yang seragam dalam riset perihal keberadaan flora dan fauna tersebut seperti : pengukuran jumlah spesies, penyebab kepunahan, maupun spesies baru yang ditemukan. Hal ini berkaitan pula dengan wewenang yang dilakukan BKSDA/BTN dalam melaksanakan inventarisasi tersebut

Ulul Albab, Vol. 4 No. 1, 2002 
tidak lepas sebagai otorita pengelola (management authority), sedangkan LIPI pada otorita ilmiah (scientific authority).

Operasionalisasi kebijakan penal yang selama ini dilakukan oleh pengelola kawasan konservasi maupun aparat penegak hukum bersandarkan pada Sistem Peradilan Pidana (Criminal Justice System) seperti yang tertuang dalam KUHAP. Dalam pelaksanaannya ditemui beberapa hal yang perlu untuk dicermati yaitu :

1. Perumusan perbuatan pidana di bidang konservasi keanekaragaman hayati seperti yang tercantum dalam Pasal 19, 21, 33 dan 44 UU No.5 tahun 1990 menunjuk-kan subjek pelaku perbuatan pidana yaitu orang, sedangkan pertanggungjawaban pidana bertolak dari asas kesalahan (asas culpabilitas) yang dinyatakan dalan unsur subjektif berupa kesengajaan dan kelalaian serta kualifikasi delik berupa kejahatan dan pelanggaran. Jenis sanksi pidana berupa sanksi pidana pokok yaitu pidana penjara, pidana kurungan dan pidana denda dengan sistem sanksi pidana kumulatif.

2. Formulasi perbuatan pidana, pertanggungiawaban pidana dan sanksi pidana dalam peraturan perundang-undangan hanya terfokus pada flora dan fauna yang dilindungi di dalam dan luar kawasan serta flora dan fauna yang tidak dilindungi di dalam kawasan. Konsekuensi yuridis normatif ini mengakibatkan ketidakpastian dan ketidakadilan bagi perlindungan hukum terhadap flora dan fauna yang tidak dilindungi di luar kawasan. Termasuk dalam hal ini adalah perlindungan hukum terhadap kekayaan plasma nutfah pada flora dan fauna yang tidak dilindungi di luar kawasan konservasi dari bahaya pengawetan atau pemanfaatan dengan cara-cara ilegal.

3. Paradigma pemahaman dan posisi keterangan ahli dalam penanganan kasus konservasi keanekaragaman hayati hanya berkisar pada kasus-kasus yang menasional atau menjadi konsumsi pers dan korbannya berupa flora atau fauna terlindungi. Realitas di lapangan menunjukkan bahwa kasus-kasus kejahatan konservasi hayati sebagian besar menggunakan keterangan ahli dari Balai TN atau Balai KSDA yaitu kepala balai, kepala sub seksi konservasi atau polhut/ petugas jagawana. Penunjukan keterangan ahli didasarkan pada surat dari instansi tersebut, sedangkan pada kasus-kasus yang menasional pihak pusat menunjuk dirjen yang membidangi masalah tersebut. Keberadaan keterangan ahli akan dibutuhkan sesuai dengan proses pemeriksaan pengadilan, baik itu oleh jaksa penuntut umum atau hakim. Selama ini inisiatif kebutuhan akan 
keterangan ahli dari pihak kejaksaan untuk meminta pada Balai menjadi saksi ahli. Seringkali polhut atau pihak pengelola konservasi melihat bahwa bukti dari TKP sudah dianggap "cukup" sehingga tidak diperlukan lagi saksi ahli. Oleh sebab itu, pemikiran tentang urgensi keterangan ahli ini berkaitan dengan kebenaran ilmiah dari objek pelanggaran maka sebaiknya inisiatif dari polhut yang pertama kali membuat laporan dari TKP.

4. Penerapan kebijakan penal di bidang konservasi keanekaragaman hayati oleh pengelola BKSDA atau BTN diterapkan pada program perlindungan dan pengamanan kawasan serta pengawasan terhadap lalu lintas perdagangan satwa.

Penerapan kebijakan nonpenal dalam bidang konservasi keanekaragaman hayati berwujud kebijakan operasionalisasi program yang tertuang dalam Keputusan Dirjen Kawasan Pelestarian Alam, Taman Buru dan Hutan Lindung. Panduan nasional tersebut dilaksanakan oleh masing-masing pengelola BKSDA/BTN akan menghasilkan program yang berbeda sesuai kondisi riil lapangan. Penentuan skala prioritas didasarkan pada kegiatan-kegiatan yang mempunyai nilai urgen bagi strategi konservasi secara in-situ maupun ex-situ sesuai sarana prasarana dan daya dukung kawasan (carrying capacity). Hasil kuesioner pada masyarakat daerah penyangga (buffer zones) di kawasan konservasi menunjukkan ketidakterlibatan secara penuh dalam mengapresiasikan program tersebut. Indikasi ini dibuktikan oleh masih tingginya tingkat ketergantungan masyarakat terhadap hasil hutan disebabkan oleh beberapa faktor seperti tradisi untuk memenuhi kebutuhan hidup sehari-hari maupun kondisi krisis ekonomi dengan tingginya tingkat pengangguran.

Dalam menerapkan kebijakan penal dan kebijakan nonpenal di atas ditemui pula bentuk kebijakan yang diambil oleh pengelolaan BKSDA/BTN. Kebijakan tersebut merupakan hasil dari kebijakan kriminal dengan pendekatan kekeluargaan. Agar anggota masyarakat yang tertangkap tangan dapat dilepaskan dengan tidak mengulangi perbuatannya dilakukan beberapa persyaratan yang termuat dalam suatu kesepakatan tertulis antara tokoh masyarakat, pengelola kawasan dan petugas jagawana. Kesepakatan ini merupakan kebijakan yang timbul didasarkan kebutuhan lapangan dan hal ini merupakan contoh dari upaya-upaya penyelesaian atau penanggulangan kejahatan konservasi keanekaragaman hayati yang dilakukan oleh masyarakat. Kendala yang dihadapi dalam proses pelaksanaan penegakan hukum konservasi keanekaragaman hayati di setiap kawasan mempunyai ciri dan cara penyelesaian yang berbeda satu dengan yang lainnya sehingga sangat tergantung 
pada situasi dan kondisi di lapangan dan tentu saja membutuhkan strategi pemikiran dan tindakan yang khas. Kendala-kendala tersebut dikaji dari persoalan yang timbul secara internal pengelola kawasan konservasi berupa : kualitas professional SDM, dana, sarana dan prasarana bagi daya dukung kawasan serta secara eksternal berasal dari gangguan luar yang mengakibatkan kerusakan maupun kepunahan flora, fauna maupun habitat.

Adapun perspektif kebijakan kriminal di bidang konservasi keaneka-ragaman hayati dalam menunjang konsep pembangunan berkelanjutan yang berwawasan lingkungan (ecologically sustainable development) diawali kajian tentang :

Re-evaluasi kebijakan penal yang ditekankan pada peng-kajian kembali terhadap beberapa hal yaitu :

1. Kebijakan formulatif. Aspek perbuatan pidana : subjek perbuatan pidana tidak hanya mengatur orang tetapi juga badan hukum, jenis perbuatan pidana meliputi delik materiel dan delik formil, serta kualifikasi delik berupa kejahatan. Aspek pertanggungjawaban pidana berupa orang dan badan hukum (korporasi) sedangkan aspek sanksi pidana yang dijatuhkan dengan sistem sanksi pidana kumulatif yaitu sanksi pidana penjara dan sanksi pidana denda serta penerapan sanksi pidana tambahan (tindakan tata tertib).

2. Dengan tidak diaturnya secara yuridis formal tentang perlin-dungan hukum terhadap flora dan fauna yang tidak dilindungi mengakibatkan proses akhir penyelesaian kasus sudah melampaui batas-batas ekologis. Dengan didasari beberapa alasan rasionalitas secara filosofis ekologis, yuridis dan sosiologis yaitu :

(a) Penetapan kriteria flora dan fauna yang dilindungi dan tidak dilindungi dalam UU/PP tidak sejalan dengan kaidah konservasi keanekaragaman hayati bahwa semua yang ada di alam dilindungi keberadaannya dari kerusakan, maupun kepunahan yang dilakukan manusia, bencana alam dan sebagainya.

(b) Pemikiran etika biologi konservasi dengan pendekatan filosofis deep ecology menyebutkan bahwa setiap spesies merupakan bagian dari komunitas makhluk hidup dan berhak untuk hidup seperti manusia. Setiap spesies memiliki nilai untuk kebaikannya sendiri, nilai intrinsik, yang tidak berhubungan dengan kebutuhan manusia. 
(c) Data lapangan menunjukkan jumlah flora dan fauna yang tidak dilindungi lebih banyak dari yang dilindungi. Disebutkan dalam lampiran PP No.7 tahun 1999 bahwa fauna yang dilindungi sejumlah 236 spesies dan flora sejumlah 58 spesies. Secara legal reasoning jenis flora dan fauna yang tidak disebutkan tergolong sebagi flora dan fauna yang tidak dilindungi.

(d) Termasuk satwa liar yang ditangkar dan dilindungi dari generasi ke II disebut sebagai satwa liar yang tidak dilindungi : Psl 11 ayat (2) PP No.8 tahun 1999

(e) Ketentuan dalam Pasal 43 ayat (1) PP No.8 tahun 1999 mengakibatkan flora dan fauna yang tidak dilindungi berubah statusnya menjadi dilindungi sesuai perkembangan faktual di lapangan.

(f) Kasus-kasus yang terjadi di lapangan menunjukkan lemahnya pelaksanaan hukum pidana untuk memberikan perlindungan terhadap flora dan fauna yang tidak dilindungi.

Dari berbagai argumentasi pendukung tersebut diperlukan pengaturan perundang-undangan yang merumuskan perbuatan pidana, pertanggungjawaban pidana dan sanksi pidana bagi pelanggar flora dan fauna yang tidak dilindungi. Demikian halnya dengan peraturan perundang-undangan terhadap kekayaan plasma nutfah pada flora dan fauna yang tidak dilindungi di luar kawasan konservasi dari bahaya pengawetan atau pemanfaatan dengan cara-cara ilegal.

3. Peristilahan flora dan fauna yang dilindungi dan tidak dilindungi membawa konsekuensi perbedaan perlakuan yuridis, baik itu dalam bidang kebijakan konservasi keanekaragaman hayati, peraturan perundang undangan maupun aspek penegakan hukum. Padahal dari segi kaidah konservasi keanekaragaman hayati semua yang ada di alam dilindungi keberadaannya dari kerusakan, maupun kepunahan yang dilakukan manusia, bencana alam dan sebagainya. Untuk itu perlu diadakan peninjauan kembali peristilahan terhadap flora dan fauna yang dilindungi dan tidak dilindungi, di dalam maupun di luar kawasan konservasi dalam peraturan perundang-undangan. Adapun peninjauan kembali peristilahan tersebut berupa metode kategorisasi yang dilakukan dengan penginventarisasian flora dan fauna secara menyeluruh sebagai hasil perkembangan faktual di lapangan dikaitkan dengan standar kategori dari IUCN dengan versi terakhir tahun 1994 maupun Appendix CITES, 
misalnya: flora dan fauna kategori I, flora dan fauna kategori II dan seterusnya. Sistem pengkategorian ini sesungguhnya merupakan instrumen yang penting dalam menempatkan posisi flora dan fauna, baik yang dilindungi maupun yang tidak dilindungi sehingga dapat tercipta harmonisasi dengan standar yang berkembang dalam kategori keterancaman spesies IUCN maupun Appendix CITES.

4. Re-orientasi pemahaman dan posisi keterangan ahli dalam penanganan kasus konservasi keanekaragaman hayati. Pemikiran tentang urgensi saksi ahli ini sangat berkaitan dengan objek pelanggaran, maka sistem yang selama ini berlangsung sebaiknya diubah, tidak lagi dari hakim atau jaksa (top down) tetapi dari bawah (bottom up) yaitu dimulai dari inisiatif petugas jagawana (polhut) yang pertama kali membuat laporan dari TKP.

5. Dalam penanganan kasus-kasus kejahatan keaneka-ragaman hayati yang terjadi di pesisir daerah penyangga (buffer zones) di kawasan konservasi dilakukan upaya-upaya penyelesaian atau penanggulangan kejahatan konservasi keanekaragaman hayati oleh masyarakat dan pengelola kawasan konservasi. Upaya tersebut merupakan metode selektifitas kriminalisasi sebagai hasil kebijakan kriminal dengan melakukan pendekatan kekeluargaan yang berwujud "kesepakatan konservasi wilayah".

Re-evaluasi kebijakan nonpenal yang dilakukan oleh pengelola kawasan konservasi, dimulai dari ide, perencanaan, pelaksanaan, monitoring, target-target yang dicapai serta pelaporan disesuaikan dengan kenyataan di lapangan. Kebijakan lokal pun dikeluarkan dalam upaya "menangkap peluang" yang muncul. Pemberdayaan kesejahteraan masyarakat yang selama ini dilakukan dengan memberikan bantuan semata tanpa melihat potensi yang terdapat dalam masyarakat diadakan perubahan dengan studi memahami desa secara partisipatif atau studi PRA (Participatory Rural Appraisal) sebagai bentuk studi yang bertujuan menggali potensi yang ada dalam masyarakat dengan pengutaraan dari keinginan masyarakat sendiri. Penggalian potensi ini akan melahirkan program-program unggulan sebagai manifestasi dari program pembinaan daerah penyangga yang bertujuan agar mengurangi tingkat ketergantungan masyarakat terhadap hutan, seperti program penangkaran, silase (tempat penanaman numput), ternak sapi, usaha koperasi dan sebagainya, termasuk program dengan LSM yaitu ekoturism. Dalam 
re-evaluasi kebijakan kriminal di bidang konservasi keanekaragaman hayati khususnya kebijakan nonpenal terbagi atas dua konsep dasar yaitu :

1) Strategi Konservasi In-Situ dan Konservasi Ex-Situ :

a) Strategi Konservasi In-situ yang terdiri atas : pengelolaan dan pengembangan wisata alam ; pengamanan kawasan: seperti penempatan petugas, operasi gabungan, operasi rutin dan lain-lain ; pembinaan habitat dan satwa ; pembangunan sarana dan prasarana;

b) Strategi Konservasi Ex-situ seperti : pembinaan daerah penyangga (dilakukan dengan studi PRA) ; pengawasan dan penerbitan perburuan ; pembinaan kader konservasi dan pecinta alam ; publikasi dan hubungan masyarakat ; koordinasi dengan instansi terkait dalam setiap pelak-sanaan program (pola kemitraan) seperti : LSM, Perguruan Tinggi, Pesantren dan lain-lain; wadah melestarikan komunitas hayati seperti : pengangkapan di lembaga konservasi dan lain-lain. Wujud dari kebijakan nonpenal tersebut merupakan gagasan yang muncul dan diaplikasikan di setiap program sehingga dapat berfungsi sebagai efek pencegahan bagi terjadinya kejahatan maupun pelanggaran di bidang konservasi keaneka-ragaman hayati.

2) Program Inti Konservasi keanekaragaman Hayati terdiri atas :

a) Kebijakan kriminal dengan pendekatan kekeluargaan

b) Program pemanfaatan potensi kawasan untuk pemberdayaan ekonomi rakyat, dengan akses masyarakat pada : aspek pemanfaatan berupa penangkaran komersial dan non komersial serta aspek jasa lingkungan berupa penggalian potensi wisata dengan studi PRA;

c) Sosialisasi kaidah konservasi keanekaragaman hayati berupa kontribusi pemikiran masyarakat dan komitmen para pihak;

d) Reposisi paradigma partisipasi konservasi keaneka-ragaman hayati melalui keterlibatan semua pihak sehingga diperlukan proses transisi konservasi keanekaragaman hayati yaitu proses perubahan pikiran dan perilaku serta;

e) Memelihara dan melestarikan nilai-nilai kearifan ekologis masyarakat.

Kebijakan kriminal di bidang konservasi keanekaragaman hayati mempertimbangkan pula rekomendasi dalam Kongres PBB tentang The Prevention 
of Crime and The Treatment of Offenders yang telah berlangsung sejak tahun 1995 sampai yang terakhir tahun 2001. Pembahasan tentang lingkungan hidup bersifat umum yang dimulai sejak kongres ke tujuh di Milan-Italia, sedangkan perlindungan flora dan fauna tidak dibahas secara spesifik.

Beberapa pertemuan internasional yang berhubungan langsung dengan kebijakan penal dalam perlindungan flora dan fauna adalah: International Meeting of Expert on The Use of Criminal Sanction in The Protection of The Environment 1994 dan XVTH. International Congress of Penal Law Crimes Against The Environment Application of The General Part in Rio de Jainero, Brazil 1994. Sedangkan kebijakan nonpenal dalam pertemuan internasional yang mendasari pengaturan hukum nasional tentang perlindungan flora dan fauna yaitu : CITES (Kepres No.43 tahun 1978) ; Dokumen KTT Bumi di Rio de Jainero tahun 1992 serta Global Biodiversity Strategy tahun 1992.

Deskripsi atas realitas sosial tentang kebijakan kriminal di bidang konservasi keanekaragaman hayati yang dilihat dari sudut pandang masa lalu, masa kini dan prediksi di masa depan menimbulkan pemikiran untuk menganalisis secara kritis dengan pendekatan holistik komparatif futuristik. Kontribusi teoritis dan praktis dalam disertasi ini dapat dimaknai sebagai cara pandang penulis dalam mengkaji kebijakan kriminal di bidang konservasi keanekaragaman hayati meliputi :

(1) pengaruh internalitas dan eksternalitas dengan prinsip-prinsip demokrasi terhadap eksistensi kebijakan kriminal dan;

(2) posisi kebijakan kriminal dalam paradigma reformasi hukum di Indonesia.

\section{G. Implikasi Hasil Temuan}

\section{Implikasi Teoritis}

Kebijakan kriminal yang diwujudkan dalam kebijakan penal dan kebijakan nonpenal dalam menanggulangi kejahatan di bidang konservasi keanekaragaman hayati dilakukan dengan pendekatan holistik, komparatif dan futuristik. Dengan melakukan pendekatan semacam ini maka akan didapatkan program-program yang dapat dilaksanakan secara optimal sehingga tujuan yang termuat dalam pembangunan berkelanjutan yang berwawasan lingkungan akan tercapai.

Ulul Albab, Vol. 4 No. 1, 2002 
Hasil temuan penelitian ini memberikan informasi-informasi penting bagi pengembangan kebijakan kriminal dengan objek penelitian kawasan konservasi keanekaragaman hayati. Dari sisi kebijakan penal yang dilakukan dengan upaya pembaharuan yaitu mengganti peraturan yang lama dengan peraturan yang baru. Perumusan dan penetapan peraturan perundang-undangan yang dikehendaki merupakan gambaran dari ekspresi norma atau nilai-nilai yang hidup dan berkembang dalam masyarakat. Kebijakan penal utamanya kebijakan formulatif merupakan kebijakan yang berusaha untuk merumuskan dan menetapkan peraturan perundangundangan yang baru di bidang hukum pidana yang sesuai dengan kondisi waktu pada saat ini maupun pada masa yang akan datang. Dengan demikian proses penetapan kebijakan formulatif ini harus mampu menghasilkan rumusan yang bersifat prediktif atau antisipatif guna mengikuti perkembangan zaman. Hal ini dapat dicermati dengan seksama perihal pengaturan tentang perlindungan hukum bagi flora dan fauna yang tidak dilindungi serta kekayaan plasma nutfah. Selain itu fokus hasil penelitian dari kebijakan penal yang menekankan pemberdayaan fungsi keterangan ahli sangat layak dikedepankan, hal ini disebabkan objek pelanggaran membutuhkan pengetahuan ilmu lain.

Dari segi kebijakan nonpenal, tawaran program-program yang dikembangkan di bidang konservasi keanekaragaman hayati lebih bersifat dinamis dan fleksibel. Hal ini ditunjang oleh kreatifitas pengelola kawasan yang menghasilkan programprogram baru yang akan berdampak positif atau multi player effect. Sifat dinamis dan fleksibel ini memungkinkan kebijakan nonpenal lebih beragam sehingga "mewarnai" kebijakan kriminal di bidang konservasi keanekaragaman hayati. Pengayaan kajian kebijakan kriminal ini dapat dilakukan dengan studi banding baik itu dari rekomendasi Kongres PBB, kesepakatan pertemuan internasional sampai studi komparatif di berbagai negara.

Upaya awal yang penulis renungkan dalam mengkristalkan cara pandang ilmuwan hukum dalam menganalisis kasus hukum yaitu paradigma positivisme hukum dan paradigma komplementaris marupakan masukan bagi dunia akademisi. Khusus kaum ilmuwan hukum diharapkan dapat mengkritisi kembali secara mendalam dari sudut pandang sejarah, teori dan filsafat hukum. Dengan berpijak pada dua cara pandang ini, penulis mengemukakan paradigma konservasi keanekaragaman hayati yang dipengaruhi oleh faktor internalitas maupun eksternalitas. Demikian halnya dengan reformasi yang bergulir saat ini yang 
menuntut perubahan dalam masyarakat memberikan pengaruh terhadap eksistensi hukum. Menelaah reformasi hukum tersebut secara teoritis dapat dideskripsikan cara pandang berupa Paradigma Reformasi Hukum di Indonesia.

Dari penelitian ini ditemukan pula beberapa permasalahan yang dapat dilakukan riset lanjutan seperti :

a. Penelitian tentang kejahatan di bidang benda cagar budaya ( berupa situs, peninggalan warisan budaya dan sebagainya ) seperti yang diatur dalam UU No.5 tahun 1992 tentang benda Cagar Budaya.

b. Terdapatnya perusahaan-perusahaan yang beroperasi di kawasan hutan lindung sehingga layak untuk diteliti berkiatan dengan kejahatan korporasi di bidang konservasi keanekaragaman hayati.

c. Penelitian terhadap korban lingkungan hidup khususnya di bidang konservasi keanekaragaman hayati.

d. Penelitian yang membahas secara mendalam tentang posisi sanksi pidana sebagai premium remedium atau ultimum remedium dalam kasus-kasus lingkungan hidup khususnya di bidang konservasi keanekaragaman hayati.

Koesnadi Hardjasoemantri membagi Hukum Lingkungan di Indonesia ke dalam 6 aspek hukum lingkungan. Salah satunya adalah Hukum Perlindungan Lingkungan. Dilatarbelakangi oleh kekompleksitasan persoalan konservasi sumber daya alam meliputi hayati dan non hayati, maka penulis menyarankan agar perlu diadakan spesifikasi hukum perlindungan lingkungan di bidang konservasi sumber daya alam hayati dan non hayati yaitu Hukum Konservasi Keanekaragaman Hayati.

\section{Implikasi Praktis}

Hasil temuan dari penelitian ini memberikan sumbangan secara praktis sebagai berikut :

a. Memberikan informasi lebih konkret tentang implementasi kebjjakan kriminal di bidang konservasi keanekaragaman hayati, terutama sisi-sisi yang harus diperhatikan dari kebijakan penal dan kebijakan nonpenal yang selama ini yang telah dilakukan oleh polhut atau petugas jagawana maupun pengelola kawasan konservasi.

Ulul Albab, Val. 4 No. 1, 2002 


\section{Saifullah}

b. Melengkapi informasi mengenai studi komparatif kebijakan kriminal di bidang lingkungan hidup oleh negara lain serta pertemuan internasional yang berkenaan dengan perlindungan flora dan fauna.

c. Menambah wawasan tentang perlunya perubahan paradigma dalam menangani kasus-kasus kejahatan konservasi keanekaragaman hayati seperti : posisi keterangan ahli, partisipasi konservasi serta pemikiran konservasi.

d. Menambah wawasan bagi pengambil keputusan khususnya pengelola kawasan konservasi untuk mempelajari dan mempraktekkan bentuk-bentuk program kebijakan penal dan kebijakan nonpenal dalam upaya penanggulangan kejahatan di kawasan konservasi.

e. Melengkapi bahan-bahan pemikiran bagi kebijakan legislatif yang berhubungan dengan revisi peraturan perundang-undangan di bidang konservasi sumber daya alam hayati dan ekosistemnya.

\section{Endnotes:}

1. Cadwell, Lynton Keith, International Environmental Policy. Emergence and Dimensions, Duke Press Policy Studies, 1984. hal. 11. Lihat juga Cooper, Richard N., Environment and Resources Policies for the World Economy, dialihbahasakan oleh Deddy Mulyana, Rosda Jayaputra, Jakarta, 1997, hal. 8

2. Cadwell. Ibid, hal 16

3. Muladi, Prinsip-prinsip Dasar Hukum Politik Lingkungan dalam Kaitannya dengan UU No. 23 tahun 1997, Jumal Hukum Pidana dan Kriminologi, Vol.I/No 1/1998, hal. 196

4. Brown, Lester R. (Ed), State of The World 1992, Worldwatch Institute, W.W.Norton \& Company, Inc, New York, 1992, hal. 15

5. Awiati, Wiwiek dan Mas Achmad Santosa, Hukum dan Kebijakan Sumber Daya Alam di Indonesia, makalah dalam Seminar Nasional "Meningkatkan Peran Hukwm dan Kebijakan dalam Pengelolaan dan Perlindungan Sumber Saya Alam Berkelanjutan", Lustrum IX Fak.Hukum UNIBRAW, Malang, 2002

5. Bryant, Dirk, Daniel Nielsen and Laura Tangley, The Last Frontier Forest. Ecosystems and Economies in The Edge, World Resources Institute, 1997, p. 11

7. Heofnagels, G.Peter, The Other Side of Criminology, Holland : Kluwer Deventer, 1973 , p. 56

8. Muladi, Opcit. Hal. 8

Ulul Albab, Vol. 4 No. 1, 2002 
9. Barda, Nawawi Arief, Penetapan Pidana Penjara dalam Perundang-undangan dalam rangka Usaha Penanggulangan Kejahatan, Disertasi, UNPAD, Bandung, 1986, hlm. 49

10. Wignjosoebroto, Soetandyo Pengolahan dan Analisa Data dimuat dalam Koentjaraningrat, Metode-metode Penelitian Masyarakat, Gramedia, Jakarta, 1981, him. 328

11. Lihat Moleong, 1995 : 179 ; Silverman, 1993 : 196-209, Miles and Huberman, 1984 ; Brannen, , 1997

\section{Bibliography}

Ancel, Marc, Social Defence. A Modern Approach to Criminal Problems, London, Routledge \& Korgan Paul, 1965

Barda, Nawawi Arief, Penetapan Pidana Penjara dalam Perundang-undangan dalam rangka Usaha Penanggulangan Kejahatan, Disertasi, UNPAD, Bandung, 1986

Branen, Julia, Memadu Metode Penelitian Kualitatif dan Kuantitatif (Alih bahasa H.Nuktah dkk), Pustaka Pelajar, Yogyakarta, 1997.

Brown, Lester R. (Ed), State of The World 1992, Worldwatch Institute, W.W.Norton \& Company, Inc, New York, 1992

Bryant, Dirk, Daniel Nielsen and Laura Tangley, The Last Frontier Forest. Ecosystems and Economies in The Edge, World Resources Institute, 1997

Cadwell, Lynton Keith, International Environmental Policy. Emergence and Dimensions, Duke Press Policy Studies, 1984.

Cooper, Richard N., Environment and Resources Policies for the World Economy, dialihbahasakan oleh Deddy Mulyana, Rosda Jayaputra, Jakarta, 1997

Heofnagels, G.Peter, The Other Side of Criminology, Holland : Kluwer Deventer, 1973

Miles, Matthew B. and A.Michael Huberman, Qualitative Data Analysis. A Sourcebook of : New Methods, Sage Publication, 1984

Moleong, Lexy,J, Metodologi Penelitian Kualitatif, Remaja Rosdakarya, Bandung, 1995

Ulul Albab, Vol. 4 No. 1, 2002 
Silverman, David. Interpreting Qualitative Data. Methods for Analysing Talk, Text and Interaction, Sage Publication, London, 1993

Wignjosoebroto, Soetandyo Pengolahan dan Analisa Data dimuat dalam Koentjaraningrat, Metode-metode Penelitian Masyarakat, Gramedia, Jakarta, 1981

\section{Bulettin, Makalah dan Jurnal :}

Awiati, Wiwiek dan Mas Achmad Santosa, Hukum dan Kebijakan Sumber Daya Alam di Indonesia, makalah dalam Seminar Nasional "Meningkatkan Peran Hukum dan Kebijakan dalam Pengelolaan dan Perlindungan Sumber Saya Alam Berkelanjutan", Lustrum IX Fak.Hukum UNIBRAW, Malang, 2002.

Muladi, Prinsip-prinsip Dasar Hukum Politik Lingkungan dalam Kaitannya dengan UU No.23 tahun 1997, Jurnal Hukum Pidana dan Kriminologi, Vol.I/No.1/1998 